\title{
Ethics in Human-Animal Relationships
}

\author{
A. ANTONITES ${ }^{1}$, J.S.J. ODENDAAL ${ }^{2}$ \\ ${ }^{1}$ Department of Philosophy, University of Pretoria, South Africa, \\ ${ }^{2}$ Research Professor, Faculty of Health Sciences, Tshwane University of Technology, Pretoria, South Africa \\ Received April 7, 2004 \\ Accepted October 26, 2004
}

\section{Abstract}

Antonites A., Odendaal J.S.J.: Ethics in Human-Animal Relationships. Acta Vet. Brno 2004, 73: 539-548.

Reactions to ethical matters related to human-animal relationships are often ambiguous and are influenced by many human-related factors. Because of such variations, there is a need for guidance in this regard. Such guidelines should thus be useful in a universal sense. Due to veterinarians position as professionally qualified persons they are often involved in debates regarding ethics related to human-animal relationships. In order to propose guidelines, philosophical perspectives were weighed against some of the latest empirical studies in animals' neurophysiology and behavioural studies. Suggested guidelines include the modalities of obligatory, desirable, admissible and indifference regarding the application of ethics in human-animal relationships. These guidelines should be valuable in human-animal relationship debates and they should provide a basis for veterinarians to be equal partners in such debates.

Ethical dilemmas, neurophysiology, behaviour, veterinary guidelines

Since recorded history of humans, animals have received contradictory standings in human ethics. Animals enjoyed deity status, were used as pretexts for the Saviour who could free people from their sins, were used in cultic sacrifices, were viewed as demons and were believed to be intermediate human forms in reincarnation. Animals were also killed mercilessly for food, products, sport, and to create safe living space for human dwellings. They were punished in public for wrong behaviour and were used as objects of experimentation and genetic manipulation. Companion animals also became intimately part of households by receiving the status of family members (Serpell 1986). This ambiguous approach is related to the way humans see themselves and how humans perceive nature, or the 'non-human' environment that includes animals. Humans may either see themselves as completely superior to their environment and animals; or they may see themselves as equal parts of the whole environment. The first view creates a certain distance between humans and animals. Nature is serviceable to humans and human considerations are the only ethical guidelines for using it. In the second view humans form such an integral part of nature that any decision regarding nature should profoundly consider environmental factors and animal needs.

The problem for ethics is that both the opposing views may contain elements of truth, despite the fact that that extremism on both sides is generally seen as unacceptable to the mainstream of thought. The ethics of the human-environment relationship will thus vary, depending on many factors falling between pure human interest and environmental ethical issues. These opposing views also allow for many intermediate views on a continuum. Further, the fact that all these views may reflect part of reality makes a universal humananimal relationship ethics a major challenge. The difficulty is not simply a matter of cultural, geographical or temporal differences, but also that within cultural groups, at different places and during different times of humanity, attitudes vary between the extremes of the continuum. To complicate the matter further, views of an individual on human-animal

Address for correspondence:

Prof. Dr. Johannes Odendaal

P.O. Box 17855

Pretoria North
Phone: +27125656090

Fax: +27125468962

E-mail: j.odendaal@ethology.co.za

http://www.vfu.cz/acta-vet/actavet.htm 
relationships may vary when they consider different issues relating to the relationship, i.e. there is not necessarily a consistency in human-animal relationships - or views may change over time during the individual's lifetime.

\section{Context of problem}

Human-animal relationships often receive attention by negative reactions towards the treatment of animals with emotional responses by lay people that constitute weak ethical arguments. Veterinarians, however, as one of the highest qualified professions in the field of human-animal relationships become involved in such ethical debates. It is imperative that veterinarians should not avoid such responsibilities, but rather offer leadership and guidance. It would not help to offer the excuse of that we are only clinically involved with people and their animals. If the veterinary profession misses the opportunity in this regard other people will speak on their behalf, which is less than desirable. A few cases are used to illustrate the problem.

In South Africa, businessmen intended to build an abattoir to sell tinned baboon meat to the public. Official and public reaction that ensued could be described as indignant. A government official said that there are reasons for concern of what the effect of baboon killings may have on the baboon population. As problem animals they can be shot without a permit. Baboons are part of the natural ecosystem and the unlimited killing of baboons could have a negative effect upon the ecosystem of the whole area. An environmental impact study must first be done before such an abattoir is to be built. Some suggested that about 65,000 baboons would be slaughtered annually and that will prevent them from becoming a 'plague'. No ethical arguments were offered, but animal rights groups reacted strongly against the idea and threatened to throw hand grenades at the abattoir (Van der Westhuizen 1999).

During the early nineties, a whale was caught by packs of ice while migrating southwards from Alaska. People observed the whale that was in dire need of freedom on international television. The United States of America (USA) Navy sent icebreakers to crack up the ice and their success at the cost of to several million dollars was celebrated widely. Some people, however, were of the opinion that too much was spent to save an individual animal's life, while the species was not threatened, and the money could have been used for human needs.

US Market Strategies carried out a poll in which the results indicated that $83 \%$ of US participants opposed Japanese and Norwegian whaling and that $70 \%$ would support the USA government to apply trade sanctions against those countries until they stop killing whales (International Foundation for Animal Welfare, 2003). In an opinion poll, 84\% of Alberta people voted against penned hunts of deer and elk (International Foundation for Animal Welfare, 2003). In another poll in the United Kingdom, a huge majority supported banning of hunting fox with hounds, while the Scottish Parliament also voted to stop hunting with dogs (International Foundation for Animal Welfare, 2001).

Humans intuitively know there is something wrong when certain animals suffer and it is possibly a universal assessment, because it came from people from divergent contexts. Since no universal ethical guidelines on human-animal relationships by practical reason exist, most of those people found it difficult to articulate the reasons why something is wrong. It illustrates the need for widely acceptable ethical guidelines on the well-being of animals. This is primarily an ethical issue of humans towards animals, because animals do not participate. Animals, despite the fact that they form the other party of the relationship, lack a theory of ethics.

Ethical guidelines do not imply an authoritarian pontificating. At grassroots there are peoples from divergent cultures and value systems. It would be a mistake to ask people to 
give up all partiality concerns. However, some habits, customs and views could be revised by the interaction of maximised perspectives including that of animal co-existence. If no universalisable maximising guidelines, which will evolve responsibilities, are developed, ambiguity and continued cruelty will prevail. Unlike local values, a maximising perspective could be acceptable if there are reasons for them. What remains universal, even in a postmodern era, is rationality. One could speak of the 'universal' amidst the 'particular'. A universal principle overrides the particular. Morality is not simply a matter of taste, emotion or non-rational attitude.

Within philosophical ethical theory there are also divergent views. Divergent views are not necessarily a problem, but it rather highlights the ambivalence and lack of clarity in animal attitudes on the theoretical level. A neutral or nihilistic attitude towards the cruelty to animals is, however, counterintuitive and irresponsible. A mere species-conservation approach will in the long term not be effective. It does not reflect the ontological responsibility in its core. The guidelines thus would be in line with the purpose of applied ethics to deconstruct established opinions and to lay bare dogmatic structures (Vorstenbosch 1993).

\section{Philosophical views on human-animal relationships}

Aquinas followed Aristotle who stated that only humans possess reason, and that sets the scene for Descartes who described animals as 'automata'. Aquinas claimed that we have no moral duties towards animals and to kill animals is indirectly morally good, because it is to the welfare of humanity in the sense that it would prevent cruelty being directed to humans.

The first explicitly dissident voice was de Montaigne (1537-1592) who wrote against cruel treatment of animals as co-sharers of the planet, but his views virtually had no impact (Braeckman 1996). Kant's approach is still in line with Descartes' thinking on animal consciousness: only humans are rational while animals and plants are devoid of this. Cruelty towards animals is not be condoned, because it reflects upon the human who inflicts the cruelty.

Clements et al. (1989) regarded animal individuals as utterly devoid of moral worth; they are mere cells of an organ, links in a food chain and evaporate eventually as temporal configurations of local perturbations in energy fields. From this Callic ot (1989) concludes that individual members of the biotic community can make no claim to such a thing as a right to live. In fact, companion animals are human products, artefacts that deserve no moral respect, and from an ecological point of view, they are plagues. Some aspects of the post Cartesian/Kantian approach are thus still relevant today.

Life, in contrast to non-life, is associated with vitalism, which means that life ought to be lived and it is intrinsically valuable and good. Schweitzer believed 'respect for life' is the solution to human-animal ethics and morally good is what promotes and keeps life for humans and animals, because all life is relevant. However, when Schweitzer (Banning 1965) was dealing with diseases where drugs could be used to kill those organisms, he revised his imperative: to promote life is good, but life, which bring life capable of development to its highest value. Bad is that, which destroys life and damages it, but impediments life which is capable of development. Goodpaster (1978) goes further than the first maxim of vitalism: he defends moral duties towards any natural entity, which is part of the natural order. The question is whether duties towards entities in the natural environment such as plants, soil, water and air can be called ethical. It would be counter-intuitive to claim that these have any interest in anything. However, air, water, minerals are intrinsically part of all living organisms and these entities are essential elements of life as such. Can they be viewed separately from life? The implications are that no air (or polluted air); no water (or polluted water); no minerals (or 
imbalances), means no life or life with diseases. Could these substances thus be harmed as part of life? Seen from an eco-ethical perspective by viewing air as providing oxygen and keeping a balance of gasses; soil as providing minerals for the body via nutrition coming from the soil; water as providing about $70 \%$ of the body mass; plants as helping in producing oxygen balances as well as food, these substances are inherent parts of human and animal life. From a holistically or global context, if the atmosphere, geosphere, hydrosphere or photosphere is damaged, the zoösphere is also negatively affected (Lovelock 1989). Ethics of life could thus include a responsibility towards the non-sentient living elements of which life is made of, not only in the sense of how those elements could affect the biological part of the world, but ontological responsibility as to its future existence. This may include ethical matters such as pollution, radiation, negative farming methods, and the destruction of vegetation and topsoil as in the rain forests. Humans share a planetary environment, a system of systems, which stands to be disrupted or upheld. One can thus argue that one does have a responsibility towards the physical environment.

From this, however, it follows that it is necessary to demarcate life as to the problem statement, viz. human and non-human animal life. It could be further narrowed down to distinguish between non-sentient and sentient animal life. Vitalism is still incomplete as a basis for arguing for moral responsibility, because its view on life is too broad. In the natural environment one could claim that all species, including the human species will look after its own interests at the cost of other species. It seems like a 'law of nature', which is also sometimes used as an argument in favour of human dominance over and exploitation of animals. In biology, however, hierarchy also means that not all life can be placed above all other considerations. This is not always negative, because to end life that suffers irreversibly could be seen as a positive attitude to quality of life. On a more negative note, food chains are a fact of life and it is accepted as part and parcel of balance in the biosphere. It is on this issue that Midgeley yielded the conviction that all species do have a preference for their own species. This is ethically acceptable within limits viz. that the interest of another species is not completely dismissed (Midgeley 1983).

Recently, it seems that contemporary utilitarianism is the dominant voice in animal ethics. Peter Singer who is an important figure in this debate brought a new way of ethical thinking by conferring moral worth to animal existences. Singer and Frey implied that both humans and animals lack moral rights, because moral rights do not exist. Especially Singer broke new ground when he argued, in conjunction with Bentham, that the issue is not whether an animal can think, but whether it can suffer. This is crucial, because beings, which can experience pain or pleasure, can be happy instead of being unhappy, do have interests. Although not wrong, it is somewhat too narrow to claim that this capacity for suffering and enjoyment is a prerequisite for having interests at all - a condition that must be satisfied before one could speak of interests in any meaningful way (Singer 1979).

One should go beyond this view to arrive at impartialist guidelines with responsibilities and therefore duties. It is necessary to reach a turning point by including relevant empirical underpinnings for such an ethics. Otherwise, to use rationality to convince will be very difficult.

\section{Empirical underpinnings for ethical considerations}

It is apparent that the 'simple' building blocks of life, the four bases of the DNA molecule, are responsible for the commonality as well as the extremely complex variations and differences in biology. It is possible that many aspects that are recognised as distinctly human characteristics could be present in at least some animals - sometimes in a more direct form, sometimes at a rudimentary level. Hierarchies in the biological world have developed due to 
characteristics of the final outcome. This would be especially true in an evolutionary approach where commonality and differences are part and parcel of kingdoms, orders, classes, families, genuses and species. One should thus be careful neither to focus solely on similarities nor on differences, because both are present. The problem is that similarities cannot be based only on exceptions or extreme examples, but it should be based rather on broad tendencies and modern techniques of detailed analysis of behavioural patterns. These aspects should be kept in mind when considering contemporary empirical insights when such findings are used as necessary theoretical tools in developing an ethical philosophical view.

Researchers in animal emotions were wary of being labelled as 'non-scientific' or anthropomorphic. However, it is now possible to ask questions such as: do animals love one another, do they mourn the loss of friends, and do they feel embarrassment? Current research in animal neurobiology is providing compelling evidence that at least some vertebrates feel a full range of emotions from fear and disgust to joy, jealousy, anger and compassion. When animals clearly express joy, anger, pleasure, distress, gratitude, analogical to humans, it is meaningless to start doubting whether the particular joy is perhaps not joy, but something else, or perhaps electrical impulses which effects a sound similar to that of joy. Physiological data do point to similarities between humans and animals in this regard. Research into the neuroanatomy and neurophysiology is the ontological sine qua non for evaluation of sentience, consciousness and rationality in animals. Studies from human brain physiology and anatomy infer conscious states, and by analogy of similarly structures in animals, make good explanatory sense of also conscious states in animals. Analogy and anthropomorphism do not go necessarily together. If one speaks of 'metal fatigue' in airplane wings, it could be called an anthropomorphic transfer from humans to planes. There are no real analogical correlates as in the case of animals. Whatever we as humans observe, describe, conceptualise and explain, are inevitable human. We can thus call all knowledge anthropological, but not anthropomorphism or anthropocentric.

This relevance of recent empirical insights enables us to transcend the Kantian-decency approach as to whether animals can be wronged more forcefully than before. Suffering may describe both physiological and mentally. It appears that signs of distress, discomfort, fear and anxiety are associated with pain in animals. The aversion among humans when seeing nonhuman animals experiencing pain evokes ethical denunciation. Evidence supports the existence of nociception (presence of pain receptors) in at least all vertebrates. Analogically, animals with nociception experience pain and distress in highly comparable ways as humans. In the brains of vertebrates the neural mechanisms implicated in what is apparently pain behaviour are very similar across vertebrate species and the feedback mechanism for controlling pain are remarkably similar. B ek off (2000) claims that emotional pain such as grief at the lost of a loved one also occurs among animals and some animals display the characteristic behaviour associated with grief in humans. Anxiety is activated by novel stimuli to increase the state of an animal's awareness, perhaps prompted by an unknown danger in an environment (Kitchen and Aronson 1987). DeGrazia and Rowan (1991) state that anxiety-mediating drugs in animals are similar to that of humans. During brain research, it appeared that the effects of compounds that cause anxiety in humans were similar in other primates.

Pleasure is something that any sentient being finds desirable for its own qualities. Goaldirected behaviour becomes possible in response to pleasant feelings, which in turn involves desires. Studies of the biochemistry associated with playing indicate that it is fun, by increased dopamine in humans and animals. According to Heinrich (as in Bekoff), ravens fall in love. Among southern right whales, romantic love develops during courtship and mating. Many birds and mammals share the brain systems and neurochemistry that underlies love in humans and all mammals have the hormone oxytocin, which is associated with courtship and bonding (B ek off 2000). 
Increasing self-awareness among animals indicates more responsibilities and duties towards them. Saying that, it follows those animals cannot be viewed in a monistic way (one species), because degrees of awareness are indeed plausible. On the 'lowest level' there is rudimentary or primitive awareness where living beings have the capacity for sense perception, but surely not the capacity for enjoyment or suffering. Primitive awareness could not be sufficient for invoking duties towards avoiding suffering and killing. Differences in degrees of consciousness are morally significant in as far as they bear upon the nature and quality of the enjoyment or suffering of the beings concerned, and becoming objects of one's own attention. Jonas' phenomenology of animal existences serves as a meaningful bridge from sentience to aspects beyond sentience. He accepts the reality of animal feelings and emotions while feeling is associated with need. A monistic explanation that all animals are driven by instincts only is thus a gross oversimplification. Insights from evolutionary and cognitive sciences have begun to revolutionise our understanding of animal minds as we share the planet with thinking animals. Autonomy (freedom), self-consciousness, transcendence and rationality go together. Necessary conditions for these are, the close relatedness and similar brain structure and activities in humans and non-human animals. Humans cannot experience certain mental states if certain parts of the brain are not functioning. The existence of similar neurological structures in animals constitutes evidence that they can have the same mental states than humans. This conclusion can be reinforced by evidence that physiology is also similarly in both parties.

Transcendence implies self-consciousness and both imply continuity and discontinuity with the environment, i.e. variance with regard the world and the self. Non-sentient or rudimentary sentient beings have an invariant and largely continuous relationship with the world. Transcendence breaks the continuity, brings distance between the self and environment. In a continental way of speaking, it means 'that you know that you know' and that you give meaning and content to the environment by means of successful interactions. Without this ability, many actions of higher primates and dolphins would not make sense. They have a wide scope of intention and can see forward to following mediate series and even end-goals. It is indeed connected with knowledge and rationality and they have shown that they can readily form a broad and complex concept when placed in a situation (Jonas 1984).

Vervet monkeys can process information at a meaning (semantic) level, and not only at an acoustic level (Che ney and S ey forth 1988). Dolphins are capable of learning complex behavioural sequences by observation and to imitate a wide variety of previously unfamiliar motion patterns and sounds, and that, without any apparent external reinforcement. Transcendence as distancing is even more apparent in dolphins. Bottlenose dolphins, in an attempt to get the attention of humans outside a tank, used imitations to convey a shared experience and dolphins also imitate seals (Tayler and Sa ay man 1972). Primates were tested for self-consciousness by using mirrors in order to stimulate them to see themselves as other animals see them (Gallup 1977). Van Den Bos and De Veer (2000) critically analysed the Mirror Self-recognition Experiment (MSE) and it appeared that human children's self-directed behaviour emerges at the age of 18 - 24 months, while chimpanzees develop the capacity for MSE at 28 - 30 months. MSE in both apes and humans was explained by the genetic link for the two species.

Self-consciousness and rationality connects with a sense of time. It is often thought that animals only have one time sense and that is the present. Evolutionary speaking, some sense of past, present and future would be highly adaptive, because the capacity to encode information gained from experience and to use that information in modifying future behaviour, makes good sense in novel situations (DeGrazia 1996). Clayton et al. (2003) concluded that some animals can recall the past and plan for or anticipate future needs. The 
memories of what they did were integrated, flexible and trial unique. Grizzly bears have been noticed that as a tactic, to locate positions from which they can observe hunters or other intrusive humans without been seen. They have also been reported to have deliberately made efforts to avoid leaving tracks. These data point to a self-consciousness and anticipation (Griffin 1992).

Rationality implies thinking, reasoning, testing, rejecting, acting on reasons, consider probabilities, having desires, making errors in calculations and to have a view of what is true or false. Intentional directedness to meaning in the world is manifested in thinking, but also behaviour in terms of non-natural meaning, and according to Noske (1993) produces nonnatural meaning. It encompasses non-material and unobservable ideation codes such as symbols, concepts and values. As in humans, non-natural meaning is evident in imitation, simulation and deception in several animals. Deception involves a further example of transcending and so rational thinking. Gorillas to other gorillas or to humans, had to retain one interpretation for themselves and present a saliently another interpretation for another, so the same action came under two descriptions for the gorilla (B ate s on 1993). It means that they are giving reasons for an act and in order to deceive, you must be able to see events from the others' perspective and negate their perception. Dolphins, apes and African Gray parrots are capable of generalisation, abstraction and concept forming apart from their ability to understand and use abstract symbols in communication. Monkeys have rich social worlds and considerable knowledge about social relations and studies have shown that they can deceive (Byrne and Whiten 1988). Both dolphins and apes have the ability to exhibit intelligent rational problem solving. They hesitate before deciding with direction to take or what first to eat. Pepperberg (1987) claims parrots have the ability to use abstract vocalisations at representational level in appropriate situations, generalise labels for colours, shapes, categories, exemplar materials and respond to entirely novel sets and randomised patterns. This indicates the capability to conceptualise quickly and code it abstractly. Examples are manifold of cetaceans deliberately assisting humans and other species when in distress at sea. A common factor here with humans is the ability to recognise what distress is. It is not reactions to species-specific signals, but the capability of abstraction.

En ard et al. (2002) reported of a single gene, which in humans provides tight control over larynx and mouth muscles. This difference as such does not diminish chimpanzee mental capabilities. Crow and Founder disputed the conclusion that an asymmetrical brain is uniquely human and being the reason that humans have language (Spinney 2004). The gap between humans and apes may result from a difference in information processing capacity, but that they have bio-linguistic substratum for language (Savage-Rumbaugh 1986). Bottlenose dolphins also learned a large number of words referring to objects, actions, properties, and relationships (Herman and Morell-Samuels 1996). A bonobo was not only capable of meaningfully understanding and employing more than 3,000 human words, but with new voice and speech synthesising technology, capable of communicating with humans.

\section{Conclusions}

If animal life has no value, moral responsibility is pointless. Capacities that were previously regarded as non-existent in animals, and belonging uniquely to humans, are now questioned. The idea of animals as mere thoughtless brutes (automata), which many still adhere to in a revised form, can now be rejected in a stronger as before. One could commit oneself to the high value of animal life and in a particular way move from the "is" towards the "ought". Referring to humans, Jonas argues that freedom (autonomy) is an ethical value by itself and evokes the feeling of responsibility (J on as 1984). In the light of the foregoing, the same applies to animal existence. This study concludes that as for humans, many animals 
manifest self-consciousness, freedom, transcendence and rationality in varying degrees, and according to biological hierarchies. What the animals are, tells us how we ought to treat them morally. The facts are connected with reasons for acting. Such moral guidelines are necessarily overriding, and sound arguments do more than expressing arbitrary preferences. Animals now become beings of serious moral concern. Important as sentience is, many animal lives now appear to be much more than sentience. Animal ways of existence were not romanticised and dissimilarities and non-analogies between humans and animals were taken into account. It appears that animals do not reflectively record history to analyse and interpret it, in nature they do not communicate in advanced symbols and writings, because they do not posses a unique alphabet of their own. Animals do not have an agreed upon legal system and thus lack institutions of law.

A discipline of human-animal ethics is a human matter that evaluates the context of animal existence, based on the knowledge of animal functions and needs. Animals do not search for the meaning of life by using religion (faith), science (testing), art (aesthetics) or philosophy (ideas) in the same way as humans do. Understanding, describing and explaining their own life-world (including human-animal relationships) are typical human endeavours. Compared to human freedom and transcendence, animals' freedom of choice is not as comprehensive and extensive. The degree of solving and gaining insight into complex problems differs vastly between humans and animals. The aim of the study was to start from grassroots level (case studies) and to eventually have results that should be again relevant to grassroots intuitions, emotions, feelings, acts and views. However, a critical morality as envisaged by this study could revise and enhance intuitions and emotions in a balanced way.

The views on sentience, self-consciousness and rationality, including the degrees thereof, are associated with hierarchies. The guidelines are thus formulated with the following modalities for responsibilities, viz. obligatory, desirable, admissible and indifferent. These responsibilities apply to suffering and the well being of animal existence. It is a responsibility to continued life of individual animals where rationality is both relevant and important.

In the light of current empirical studies, some animals' sentience and rationality stand on the highest level in animal hierarchies. Coherent to ontological-ethical values of rationality and self-consciousness, it follows that that the lives of individuals of such species are inviolable and may not be treated cruel indiscriminately. Their moral modality would thus be the obligatory. As with humans, their sentience, self-consciousness and rationality function as a unity. This gives their emotional and others ways of living a profound richness. Although we do not pursue the issue of legal rights, but ethical guidelines, it became clear that the value of the highest order or modality of animals' lives, are non-negotiable or expendable. This view may be extended by further guidelines consistent with those just stated, viz. that these animals may not be used for human purposes such as laboratories research. Humans have a prima facie duty not to confine them against their will (unless for their own protection), and we may not harm them. They are indeed ends in themselves and not means to human ends.

The next level is the desirable. This also involves a moral guideline where the presumption against killing or harming is strong, but less categorical than the first. To harm these animals' ability to function in a way that interferes with their ability to live a good life is undesirable. The desirable is thus also a guideline of efficiency.

Admissible would imply that e.g. confinement could in cases be acceptable. An accidental killing would be judged as less serious. Conscious beings in this modality such as fish have an interest in a happy life and as little unhappiness and pain as possible. It does, however, not mean that an animal here has a personal interest in continuing to live. Death is a cessation of experiences, in much the same way as birth is the beginning of experiences. The latter would refer to the first two modalities. 
As with the highest level, the lower level of indifference is more categorical. This refers to insects and lower animals as individuals. As individuals they have no perspective of their own and they do not have moral status. Amoebae, from a biosphere perspective may have an eco-ethical value, but then as a species and not as individuals.

These guidelines and modalities imply that not only the lives of humans are to be given equal consideration, but not equal treatment. There will be many borderline cases as this is a complex issue, however, borders between species are decided by humans, and could thus be applied arbitrarily. This approach is different from a modernist mere application of principles. It would be a prudential universalism, not a determinant, but guide to the wellbeing of animals in our planetary environment. Instead of merely prescribing maxims of responsibility as valid, they are regarded as serious starting points for further discourse. Universal conclusions should become universalisable in concrete terms, meaning that in procedural terms and resting on rational consensus, the end-goal would be acceptance of such conclusions on an international level. These guidelines are less complex than those of utilitarianism and will hopefully contribute to include emotions, and intuitions, and provide more clarity in cases of ambivalence. In this way the stated central problem is addressed. Ethical considerations regarding the human-animal relationship are a matter of a balanced approach, especially in desirable and admissible cases. In all cases speciesism, favouring only our own species is unacceptable. A balanced approach will consider that rational sentient lives as capable of leading a life that is happier or less miserable than some alternative life. Balance will understand that there are humans who are below the level of self-conscious rationality than some non-humans. Unfortunately, a balanced approach by humans cannot always be guaranteed or defined. Extremism is often more easily defined and should always be unacceptable on both sides of the spectrum related to animal welfare and well-being.

There is but one way to promote ethical considerations in human-animal relationships and that is by education. This includes parents as adult role models, formal and informal education as well as adult continuing education. It will encourage people to think about life and their responsible roles in life-systems. Such knowledge will affect attitudes to life in a positive way, paving the way for a balanced ethically approach to human-animal relationships where clarity and informed decision-making becomes possible. Species hierarchy is a natural phenomenon, but it should be applied with responsibility and based on the latest empirical knowledge. A balanced responsible approach aims for optimal relationships and it overrides extremism. Education can thus enhance future ethical decisions regarding this phenomenon by developing balanced and responsible attitudes. History has shown that traditional attitudes can change based on new knowledge and insights, and there is no reason to believe that human attitudes to animal life cannot also change. These guidelines should be valuable in human-animal relationship debates and they should provide a basis for veterinarians to be equal partners in such debates.

\section{Etika ve vztazích lidí a zvířat}

Reakce na etické otázky spojené se vztahem člověka ke zviřatům bývají často dvojznačné, a pod vlivem četných faktorů závislých na lidském nazírání. Existence takových rozdílů proto vyžaduje návod jak tyto otázky posuzovat. Návod by měl být použitelný $\mathrm{v}$ univerzálním smyslu. Veterináři jsou profesionálně kvalifikovanou skupinou a proto bývají často zapojeni v debatách o etických problémech vztahu člověka a zviŕat. Aby bylo možné připravit návod $\mathrm{k}$ postupu, srovnáváme filozofické perspektivy a nejnovější empirické neurofyziologické a behaviorální studie. Navrhovaný návod proto zahrnuje modality povinné, žádoucí, přípustné a indiferentní pro aplikaci etiky ve vztahu člověka a zvířat. Tento návod by měl být cennou pomůckou v debatách o těchto otázkách a veteriná- 
řům by měl poskytnout základ $\mathrm{k}$ tomu, aby se stali rovnocennými partnery $\mathrm{v}$ takových diskusích.

\section{References}

BANNING, W 1965:Typen van Zedeleer. De Erven \& Bohn, Haarlem, 76 p.

BATESON, P 1993: Humans, nonhumans and personhood. In: The Great Ape Project, (eds.) Cavalier, P and Singer, P. Frank Estate. London, pp. 237-238

BEKOFF, M 2000: Beastly passions. 29 April: 32-36

BRAECKMAN, J 1996: Ethiek en het gedrag van mensen tegenover dieren een historisch oversicht. Vlaams DieregeneeskundeTijdschrift, 65: 184

BYRNE, RW, WHITEN, A 1988. Machiavellian intelligence. Clarendon, Oxford, 186 p.

CALLICOT, J B 1989: In defense of the land ethics: essays in environmental philosophy. Suny Press, Albany, $89 \mathrm{p}$.

CHENEY, DL, SEYFARTH, RM1988: Assessment of meaning and the detection of unreliable signals by vervet monkeys, Animal Behavior 36: 483

CLAYTON, N, BUSSEY, TJ, DICKISON, A 2003: Can animals recall the past and plan for the future? Nature Reviews, Neuroscience 4: 685-691

CLEMENTS, F, TANSLEY, A, ELTON, C, CALLICOT, JB 1989: In defense of the land ethics: essays in environmental philosophy. Suny Press, Albany, pp. 89-90

DeGRAZIA, D 1996: Taking animals seriously - mental life and status. Cambridge University Press, Cambridge $170 \mathrm{p}$.

DeGRAZIA, D., ROWAN, A. 1991: Pain, suffering and anxiety in animals and humans. Theoretical Medicine 12: 204-205

ENARD, W, PRZEWORSKI, M, FISHER, SE, PÄÄBO, S, LAI, CS, WIEBE, V, KITANO, T, MONACO, AP 2002: Molecular evolution of FOXP2, a gene involved in speech and language. Nature 418: 869-872

GALLUP, GG (Jr) 1977: Self-recognition in primates - a comparative approach to the bisectional properties of consciousness. American Psychologist, May: 339

GOODPASTER, KE 1978: On being morally considerable. Journal Philosophy 75: $308-325$

GRIFFIN, D 1992: Animal minds. The University of Chicago Press, Chicago 249 p.

HERMAN, LM, MORREL-SAMUELS, P 1996: Knowledge acquisition and asymmetry between language comprehension and production: dolphins and apes as general, models for animals. In: Bekoff, M and Jamieson, D Readings in Animal Cognition. Mass: The MIT Press, Cambridge 296 p.

INTERNATIONAL FOUNDATION FOR ANIMAL WELFARE. 2001: Historic vote to abolish fox hunting in Scotland by Animal Welfare Groups. In: Environmental News, http://www.enn.com accessed on 19 September INTERNATIONAL FOUNDATION FOR ANIMAL WELFARE. 2002: Eighty four per cent of Alberta, Canada voters now opposed to penned hunts. Environmental News, http://www.enn.com accessed on 17 July

INTERNATIONAL FOUNDATION FOR ANIMAL WELFARE. 2003: New National Poll shows voters strongly against commercial whaling. Environmental News, http://www.enn.com accessed on 18 June

JONAS, H 1984: The imperative of responsibility - in search of an ethics for the technological age. Chicago University Press, Chicago pp. 59-65

KITCHEN, H, ARONSON, AL 1987: Panel report on recognition and alleviation of animal pain and distress. J Amer Vet Med Assoc 19: 1187

LOVELOCK, J 1989: The ages of Gaia - a biography of our living earth. Oxford University Press, Oxford, pp. 3-14 MIDGELEY, M 1983: Animals and why they matter. University of Georgia Press, Athens, 102 p.

NORRIS, KS, DOHL, T 1980: The structure and function of cetacean schools. In: Herman, L. Cetacean behavior mechanisms and functions. John Wiley and Sons, New York, $265 \mathrm{p}$.

NOSKE, B. 1993: Great apes as anthropological subjects - deconstructing anthropocentrism. In: Cavalieri, P. and Singer, P. The great ape project - equality beyond humanity. Fourth Esta, London, 262 p.

PEPPERBERG, IM 1987: Evidence for conceptual quantitative abilities in the African Grey Parrot. Ethology, pp. 57

SAVAGE-RUMBAUGH, S 1986: Ape language - from conditioned response to symbol. New York, pp. 260-263

SCHWEITZER, A 1965: Quoted in Banning, W: Typen van zedeleer. De Erven, F. \& Bohn, N.V., Haarlem

SERPELL, J 1986: In the company of animals. Basil Blackwell Ltd., Oxford, 178 p.

SINGER, P 1979: Practical ethics. University Cambridge Press, Cambridge, 50 p.

SPINNEY, L 2004: Nonhuman brain asymmetry doubts. The New Scientists, 15 March: 14

TAYLER, CK, SAAYMAN, GS 1973: Imitative behavior by Indian Ocean bottlenose dolphins (tursiops) in captivity. Behavior pp. 289-291

VAN DEN BOS, R, DE VEER, M 1999: A critical review of methodology and interpretation of mirror self recognition research in nonhuman primates. Animal Behavior 58: 463

VAN DER WESTHUIZEN, C 1999: Kalf is nie familie nie, maar bobbejaan? Beeld, Johannesburg, 22 May: 4

VORSTENBOSCH, J 1993: Four ways of leaving the ivory tower - perspectives on research in applied ethics. In: Heeger, R, WILLIGENBURG, A The turn to applied ethics. Kok Pharos Publishing House, Kampen, pp. 43-44 